\title{
ХВОРОБА ЛАЙМА У ДІТЕЙ НА СУЧАСНОМУ ЕТАПІ
}

\author{
Львівський національний медичний університет імені Данила Галицького
}

Мета роботи - узагальнити нові дані про етіологію, епідеміологію, клінічні прояви та лабораторну діагностику хвороби Лайма (ХЛ) у дітей, навести сучасні рекомендації щодо ії вчасної профрілактики та лікування.

На підставі огляду літератури наведені найновіші дані про хворобу Лайма у дітей. Узагальнено інорормацію про етіологію, епідеміологію, характерні клінічні симптоми та перебіг Лайм-бореліозу (ЛБ) в педіатричній практиці. Описано сучасні методи діагностики і лікування Лайм-бореліозу, вказані дози і препарати залежно від стадії і форми захворювання, які затверджені Центрами контролю та профрілактики захворювань США (CDC) та товариством з інфекційних хвороб США (Infectious Diseases Society of America, IDSA) для лікування ХЛ в педіатрії. Наведені рекомендації стосовно профрілактики хвороби Лайма.

Епідеміологічні дані з багатьох країн Європи та США свідчать про значне зростання діагностованих випадків Лайм-бореліозу завдяки використанню в лікарській практиці таких високоінформативних методів діагностики, як імунофрерментний аналіз (ІФА) та імуноблот. На сьогодні є багато інформації та наукових досліджень Лайм-бореліозу в дорослих, на відміну від дітей. Саме тому наш літературний огляд присвячений хворобі Лайма в педіатричній практиці.

Ключові слова: хвороба Лайма, іксодові кліщі, імуноблот, Лайм-артрит, Лайм-кардит, діти.

Хвороба Лайма (кліщовий бореліоз, Лайм-бореліоз) - це інфекційне природно-осередкове трансмісивне захворювання, яке спричиняється бактеріями комплексу Borrelia burgdorferi sensu lato (Bbsl) і характеризується переважним ураженням шкіри, серцево-судинної системи, нервової системи та опорно-рухового апарату [1].

\section{Етіологія}

Збудник хвороби Лайма - грамнегативна спірохета з родини Spirochaetaceae, роду Borrelia. За своєю структурою це рухливі спірохети, що нагадують штопороподібну звивисту спіраль. Борелії не утворюють токсинів, але мають три групи антигенів: поверхневі, джгутиковий та цитоплазматичний. Поверхневі антигени - це білки зовнішньої оболонки (Osp-outer space protein, OspA, OspB, OspC, OspD, OspE, OspF й ін.), які є основними антигенами і єдиним фрактором вірулентності борелій [2].

До складу комплексу Borrelia burgdorferi sensu lato входить близько 18 різних видів борелій. Дев'ять 3 них, a came $B$. americana, $B$. andersonii, B. californiensis, B. carolinensis, B. japonica, B. tanukii, B. turdi, B. sinica та B. yangtze, ще не було виділено від людини, тоді як 9 інших видів (B. afzelii, B. bavariensis, B. bissettii, B. burgdorferi sensu stricto, B. garinii, B. kurtenbachii, B. Iusitaniae, B.spielmanii та B. valaisiana) володіють патогенним потенціалом для людини. На сьогодні лише 3 види борелій найчастіше спричиняють Лайм-бореліоз, a came Borrelia burgdorferi sensu stricto (Bbss), Borrelia garinii та Borrelia afzelii. Borrelia burgdorferi sensu stricto поширена в Північній Америці та Європі. B. garinii, яка асоціюється з ураженням нервової системи, та $B$. afzelii, яка пов'язана з ураженням шкіри, переважають в Європі та Азії, але відсутні в Північній Америці [3].

\section{Епідеміологія}

Лайм-бореліоз - це зоонозна інорекція з трансмісивним механізмом передачі.

Для захворювання характерна весняно-осіння сезонність. Природними резервуарами для борелій $€$ гризуни, птахи, олені та велика рогата худоба. Зараження людини настає при укусі кліща, інорікованого бореліями [4].

Основна частина України ендемічна за цим зоонозом. Найвищий рівень захворюваності на ЛБ реєструється в її західному регіоні. Офріційна реєстрація хвороби Лайма в Україні ведеться з 2000 року. Рівень епідеміологічної реєстрації щороку зростає: показник захворюваності на Лайм бореліоз в Україні з 2000 року за 10 років зріс у 29 разів [5].

В Україні циркулює 5 геновидів борелій комплексу Borrelia burgdorferi sensu lato: $B$. burgdorferi sensu stricto (Bbss), B. afzelii, B. garinii, B. valasiana, A14S [1].

Єдиними переносниками борелій від тварини до людини є іксодові кліщі. На території США переважають кліщі Ixodes scapularis, для території Північної Америки 


\section{ОГЛЯДИ ТА ЛЕКЦІї}

та Азії характерні кліщі I. расіficus, для території Європи - I. ricinus.

Цикл розвитку іксодових кліщів триває два роки. За цей час кліщ проходить 4 стадії розвитку: яйце, личинка, німфра та доросла особина. Тільки личинки, німфри та дорослі самки кліщів потребують кров для життєдіяльності і лише кліщі на стадіях німф і дорослих особин можуть передавати B. burgdorferi. Самки кліщів відкладають яйця навесні, влітку з них з'являються личинки. Наступної весни з личинки утворюється німфра, з якої восени розвивається доросла особина кліща - імаго. Кліщі заражаються бореліями, харчуючись на інфрікованих тваринах. Личинки і німфи харчуються на дрібних тваринах (полівки, миші). Доросла особина - на більших тваринах, найчастіше це олені. Єдиним резервуаром B. burgdorferi є дрібні гризуни, а олені відіграють важливу роль для виживання збудника взимку. Іксодові кліщі також $€$ переносниками кліщового енцефаліту, моноцитарного ерліхіозу, гранулоцитарного анаплазмозу людини та бабезіозу.

Борелії містяться в кишківнику кліщів і зі слиною переносяться в місце укусу, спричиняючи інфрікування [6]. Передаватися збудник від кліща до людини може також лімсогенним та периневральним шляхом, залежно від місця укусу. Борелії можуть набувати неактивних форм, які за несприятливих умов не мають антигенного впливу. Однак при створенні сприятливих для збудника умов він завдає антигенний вплив [7].

\section{Клінічна картина}

У перебігу хвороби Лайма виділяють 3 стадії: рання локалізована, рання дисемінована та пізня дисемінована.

Зазвичай клінічні прояви недуги у дітей і дорослих схожі, крім менінгополірадикулоневриту (синдром Баннварта) й хронічного атрофрічного акродерматиту, які $€$ нетиповими проявами для дітей [8].

\section{Рання локалізована стадія}

Первинна мігруюча еритема (ME) $є$ основною клінічною ознакою для ранньої локалізованої стадії хвороби Лайма. Може виникати через 3-30 діб (в середньому 7-14) після укусу кліща [9]. У дітей найчастіше виявляють кліщів на волосистій частині голови, в ділянці вушних складок, навколо пупка. Мігруюча еритема не підвищується над рівнем шкіри (можуть підніматися незначною мірою лише краї ME), не болюча, лущення не характерне. Але ME може супроводжуватися свербежем та відчуттям печіння [10]. Діаметр ME не менше 5 см є її діагностичною ознакою. Сама еритема може бути у вигляді мішені або гомогенно забарвлена. У центрі еритеми може виникати некроз, що свідчить про силу імунної відповіді. 3 кожним днем МЕ збільшується у розмірі і може досягати 70 см в діаметрі [11].
У більшості випадків хвороба Лайма супроводжується наявністю МЕ. Проте $є$ дані, що у 20-40 \% випадків Лайм-бореліоз перебігає в безеритемній фрормі, що значно утруднює діагностику захворювання [12].

Крім шкірних проявів рання локалізована стадія характеризується інтоксикаційним синдромом (підвищення температури тіла, остуда, міалгії, артралгії, біль голови).

Одтальмологічні симптоми виникають зазвичай рідко і найчастіше проявляються кон'юктивітом в ранній локалізованій стадії Лайм-бореліозу. Інколи можуть виникати увеїт, кератит та епісклерит.

Мігруюча еритема - це клінічний діагноз. Серологічні дослідження у пацієнтів з ранніми проявами захворювання можуть бути негативні, але позитивні результати не підтверджують діагноз ME, так як фронова серопозитивність висока в ендемічних регіонах. Також раннє призначення антибіотикотерапії може послабити вироблення антитіл, що призведе до негативних результатів серологічних досліджень. Якщо клінічно є підозра на атиповий прояв ME, виявлення спірохет в біоптатах з підозрілих ділянок за допомогою культурального дослідження і/або ПлР є важливим в підтвердженні інфекції, спричиненої B. burgdorferi s.I. [13].

Якщо на ранній локалізованій стадії пацієнт не отримує лікування - еритема зникає, і в третини хворих захворювання не розвивається, а в 2/3 хворих переходить у наступну стадію.

На цій стадії ME слід дисеренціювати з дерматомікозами, запаленням підшкірно-жирової тканини, реакцією гіперчутливості на укус кліща, яка зазвичай менша 5 см в діаметрі з характерним свербежем, контактним дерматитом, кропив'янкою [14].

Рання дисемінована стадія (друга стадія) розвивається, якщо пацієнт не отримує необхідне лікування під час ранньої локалізованої стадії. Рання дисемінована стадія починається через 3-5 тиж після укусу кліща і супроводжується появою множинної мігруючої еритеми внаслідок гематогенної дисемінації збудника. Елементи множинної мігруючої еритеми менші, ніж первинна ME, вони не збільшуються в розмірі з часом і швидко зникають.

Параліч черпних нервів, особливо лицевого, доброякісна внутрішньочерепна гіпертензія, менінгіт і кардит можуть спостерігатися у дітей під час ранньої дисемінованої стадії.

Лімфоцитарний менінгіт, нейропатія черепних нервів і радикулоневрит є класичною тріадою гострого раннього неврологічного Лайм-бореліозу [15].

Рідкісним шкірним проявом ранньої дисемінованої стадії Лайм-бореліозу у дітей є бореліозна лімсоцитома (БЛ) - одиничний синювато-червоний утвір, який най- 
частіше локалізується в ділянці мочки вуха, сосків або калитки і частіше трапляється у дітей, ніж у дорослих. За відсутності відповідного лікування лімфоцитома може зберігатися місяцями і поєднуватися з іншими проявами Лайм-бореліозу. Як правило, на момент звернення, пацієнти з бореліозною лімфоцитомою $є$ серопозитивними. Гістологічне дослідження необхідне у випадку діагностичної невизначеності для виключення діагнозу лімсроми шкіри або інших злоякісних утворень. БЛ має типовий гістологічний вигляд щільного, дифузного лімфоцитарного інорільтрату з плазматичними клітинами по всій дермі, який рідко поширюється в епідерміс. Часто помітні лімфоїдні фролікули із зародковими центрами, які, на відміну від інших В-клітинних псевдолімфом, як правило, не мають мантійної зони. Бореліозна лімфоцитома дуже рідко реєструється в США, але добре знана в Європі [16].

Нейробореліоз може проявлятися залученням у процес: черепно-мозкових нервів (параліч), периферичної нервової системи (радикулонейропатія, яка може проявлятися онімінням, поколюванням, «стріляючим» болем або слабкістю в руках чи ногах), центральної нервової системи (Лайм-менінгіт) [17].

Клінічні прояви ураження нервової системи при Лайм-бореліозі зазвичай починаються через 2-18 тиж після укусу кліща. Мігруюча еритема не завжди їм передує. Менінгорадикуліт і радикулоневрит, класичні форми нейробореліозу в дорослих, зазвичай не діагностуються у дітей. Діагноз нейробореліозу може базуватися на симптомах менінгізму з болем голови чи без нього, дратливістю, млявістю і може бути асоційований з паралічем черепно-мозкових нервів. Ураження черепних нервів найчастіше проявляється паралічем лицевого нерва (VII пара). Двобічний параліч лицевого нерва $€$ важливим діагностичним критерієм хвороби Лайма.

Для діагностики Лайм-менінгіту проводять спинномозкову пункцію. При аналізі ліквору виявляють лімфоцитарний плеоцитоз, нормальний рівень глюкози, незначно підвищений рівень білка, що потребує діагностичного пошуку для виключення менінгіту вірусної етіології. Для остаточного підтвердження нейробореліозу необхідне виявлення інтратекального синтезу антитіл до борелій. Паралельно з дослідженням ліквору слід визначати антитіла до борелій у сироватці крові та блот-аналіз. У типових випадках гострого нейробореліозу виявляється лише позитивний $\lg М$ до борелій, позитивні IgG з'являються пізніше [18].

Лайм-менінгіт у дітей за ознаками і симптомами подібний до перебігу вірусного менінгіту. У клінічній практиці є правило семи, яке застосовують для прогнозування Лайм-менінгіту: діти з болем голови, який триває менше 7 діб, наявністю мононуклеарів у спинномозковій рідині менше 70 \% і з відсутністю паралічу 7-ї пари (або іншої) черепних нервів класифрікуються як такі, що мають низький ризик розвитку Лайм-менінгіту [19].

Рідкісні прояви нейробореліозу у дітей включають: міоклонію, атаксію, запаморочення, поліневрит черепномозкових нервів, за винятком паралічу лицевого нерва, гострого поперечного мієліту та доброякісної, ізольованої внутрішньочерепної гіпертензії. Також повідомлялися рідкісні випадки гострого дисемінованого енцефаломієліту та цереброваскулярних ускладнень, зокрема інсульту [20] .

Зазвичай клінічний перебіг нейробореліозу у дітей легший і коротший порівняно з дорослими. На МРТ головного мозку у дітей з нейробореліозом можуть виявляти розширені простори Вірхова-Робіна та Т2-гіперінтенсивні вогнища [21].

\section{Лайм-кардит}

y 1980 p. Steere et al. вперше описали симптоми Лайм-кардиту [22]. Прояви ураження серцево-судинної системи починаються через 2-5 тиж від появи ME, хоча діапазон може бути від менше 1 тиж до 7 міс. Лише третина пацієнтів, в яких розвинувся Лайм-кардит, пригадує про укус кліща[23].

Кардит у дітей з хворобою Лайма може супроводжуватися відчуттям серцебиття, головокружіння, синкопальними станами, болем у грудній клітці [24].

Атріовентрикулярна блокада - найпоширеніший прояв Лайм-кардиту як у дорослих, так і у дітей. Ступені АВ-блокади можуть швидко змінюватися і прогресувати аж до 3-го ступеня і раптової смерті.

Рідше Лайм-кардит може проявлятися гострим міокардитом, перикардитом, міоперикардитом, ендокардитом і панкардитом. Лайм-кардит може спричинити клапанні ураження серця і призвести до гострої серцевої недостатності та кардіогенного шоку [25].

Haddad et al. [26] описали клінічний випадок ураження мітрального клапана у жінки 65 років внаслідок хвороби Лайма. Пацієнтці було замінено клапан і призначено антибіотикотерапію цеотріаксоном. Впродовж 6 міс. спостереження за станом здоров'я пацієнтки відновлення симптомів чи повторного ураження клапанів не було.

Клінічні прояви міокардиту можуть відрізнятися залежно від віку і ступеня тяжкості недуги. У дітей та підлітків можуть спостерігатися симптоми з боку органів дихання, ШКТ та серцево-судинної системи у вигляді колапсу. На відміну від дітей, дорослих в 65 \% випадків турбує біль у грудях.

На ЕКГ може реєструватися брадикардія, АВблокади різного ступеня, блокади ніжок пучка Гіса [27].

Основою лікування Лайм-кардиту є моніторинг фрункцій серця, підтримувальна та антибіотикотерапія. 
У деяких випадках може знадобитися встановлення кардіостимулятора. Кортикостероїди не скорочують тривалість захворювання і зазвичай не рекомендуються для лікування Лайм-кардиту.

Лайм-кардит, включаючи випадки АВ-блокади високого ступеня, як правило, повністю лікується за допомогою антибіотиків. Маркер високого ризику прогресування AB-блокади аж до повної - це початковий PR інтервал >300 мс під час первинного звернення пацієнта [28].

\section{Пізня дисемінована стадія}

Пізня стадія хвороби Лайма у дітей найчастіше супроводжується артритом. У дорослих, крім артриту, вона може супроводжуватися хронічним атрофрічним акродерматитом і пізнім ураженням нервової системи.

Пізній нейробореліоз (НБ) виникає приблизно в 50 разів рідше, ніж ранній НБ. Найтиповішими проявами пізнього нейробореліозу є ураження головного мозку у вигляді прогресуючого енцефаломієліту, енцефралопатії та периферичної нейропатії. Типовими симптомами $€$ спастично-атактична хода, розлади сечового міхура та прямої кишки, нервово-психічні синдроми. Характерний повільний прогресуючий перебіг без больового синдрому [29]. При підозрі на пізній НБ потрібно провести диференційну діагностику з дисемінованим енцефраломієлітом (Encephalomyelitis disseminata) й нейросифрілісом. Для підтвердження діагнозу обов'язкова спинномозкова пункція. Ще одним проявом пізнього НБ є полінейропатія, поєднана з хронічним атрофрічним акродерматитом. Полінейропатія при пізньому НБ спричинена дегенерацією аксонів, характеризується асиметричним розподілом і виникає після ураженням шкіри [30]. За словами Wormser GP et al. [31], Лайм-бореліоз рідко є справжньою причиною полінейропатії у дорослих, на відміну від дітей. Інші причини (наприклад, цукровий діабет або вживання алкоголю) значно частіші. Виявлення позитивних антитіл до борелій у пацієнтів з полінейропатією буває випадковою знахідкою в більшості випадків.

Лайм-артрит, як правило, починається через декілька місяців після контакту з інорікованим кліщем. Він часто маніфестує як періодичний або стійкий моноартикулярний або олігоартикулярний артрит, який зазвичай уражає 1 або 2 суглоби одночасно. При моноартикулярному типі найчастіше уражається колінний суглоб. Як правило, спостерігається значний його набряк, шкіра над суглобом гіперемована, характерне обмеження рухів у ньому. Інтенсивність болю відрізняється, хоча Лайм-артрит, як правило, не $є$ надто болючим, як це спостерігається при септичних артритах, але у деяких дітей при ходьбі виникає кульгання.

Лайм-артрит може маніфестувати як асиметричний олігоартрит. При олігоартриті коліно уражається разом
3 іншим великим суглобом, наприклад кульшовим, плечовим, гомілково-ступневим, ліктьовим, скронево-нижньощелепним або променево-зап'ястковим суглобом. Також уражаються сухожилля, зв'язки або бурси. Оскільки ранню стадію хвороби Лайма зазвичай розпізнають і ефективно лікують антибіотиками, на сьогодні Лаймартрит спостерігається в пацієнтів із мінімальними або відсутніми симптомами раннього ЛБ. Дуже часто артрит може бути єдиним проявом Лайм-бореліозу у дітей. Пацієнти з Лайм-артритом мають найвищі титри антитіл IgG, які можна виявити при хворобі Лайма [32].

Водночас симптоми при Лайм-артриті (ЛА) бувають різноманітними: від набряку в ділянці суглоба і дискомфорту під час ходьби до проявів, схожих на септичний артрит. Саме тому ЛА тяжко віддиференціювати від септичного артриту або неінфекційних артритів, таких як олігоартикулярний ювенільний ревматоїдний артрит або транзиторний синовіїт.

Пацієнти з Лайм-артритом мають тенденцію до підвищення рівня запальних маркерів крові, таких як лейкоцити, ШОЕ і ЦРП порівняно з пацієнтами, в яких наявний транзиторний синовіїт.

Порівняно 3 пацієнтами зі септичним артритом, в осіб з Лайм-артритом частіше уражається колінний суглоб і вони рідше повідомляють про гарячку в анамнезі [33].

У більшості пацієнтів Лайм-артрит успішно піддається лікуванню доксицикліном або цефртріаксоном у правильній послідовності. Однак близько $10 \%$ пацієнтів у США мають Лайм-артрит, рефррактерний до антибіотикотерапії. Критеріями ЛА, стійкого до антибіотикотерапії, є: активний артрит більше 2 міс. після завершення АБ-терапії, більше 8 тиж перорального прийому антибіотиків або більше 2 тиж парентеральної антибіотикотерапії чи персистуючий артрит протягом понад 3 міс. після 1 міс. антибіотикотерапії. Факторами ризику ЛА, рефрактерного до АБ-терапії, $є$ вік більше 10 років, тривалий перебіг артриту до початку лікування, погіршення симптомів артриту після початку антибіотикотерапії [32]. У дітей з ЛА прогноз після адекватної антибіотикотерапії кращий, ніж у дорослих у зв'язку з меншою кількістю рефрактерних випадків.

\section{Хронічний атрофічний акродерматит}

Хронічний атрофрічний акродерматит (XАA) - це шкірний прояв пізньої стадії Лайм-бореліозу, який спостерігається майже винятково в Європі. Він розвивається через місяці, іноді роки, після зараження борелією комплексу B. burgdorferi s.l. і найчастіше викликається came Borrelia afzelii. Хоча хронічному атрофрічному акродерматиту може передувати мігруюча еритема й інші прояви хвороби Лайма, але зазвичай він розвивається як перша і єдина ознака Лайм-бореліозу. 
Шкірні прояви починаються 3 почервоніння шкіри, як правило на дорсальній поверхні стопи або долоні. Почервоніння дуже повільно поширюється, набуваючи синюватого забарвлення, з'являється місцевий набряк. Через декілька місяців, іноді років, набряки поступово зникають, а шкіра стає все більш атрофічною. Гістопатологічна картина хронічного атрофічного акродерматиту не $є$ діагностичною, але $є$ достатньо характерною, щоб насторожити досвідченого гістолога.

Гістологічно на початковій набряковій стадії спостерігається інфільтрація лімфоцитами, плазматичними клітинами і гістіоцитами, на пізній стадії - атрофрія дерми, яка супроводжується втратою еластичних волокон і волосяних фролікулів, атрофрією епідермісу та інфрільтрацією плазматичними клітинами навколо розширених судин дерми [34].

ХАА слід підозрювати у пацієнта із синювато-червоним забарвленням кінцівки з набряком або без нього, 3 атрофрією чи без.

Як було зазначено, ХАA реєструється в Європі, на відміну від Північної Америки. Ця географрічна відмінність пояснюється тим, що у Північній Америці В. burgdorferi sensu stricto $€$ майже основною причиною Лаймбореліозу, тоді як в Європі основними збудниками хвороби $є$ B. afzelii та $B$. garinii, і лише рідко - B. burgdorferi sensu stricto. Хоча ХАА головним чином асоціюється 3 інфекцією $B$. afzelii, B. garinii та B. burgdorferi sensu stricto також виділяють від окремих пацієнтів. За даними Cerar et al. (2016) [34], відсутність автохтонного ХАА в Північній Америці та виділення B. burgdorferi sensu stricto зі шкіри деяких Європейських пацієнтів з ХАА видається суперечливим, але свідчить про те, що північноамериканські та європейські B. burgdorferi sensu stricto генетично схожі, проте відрізняються щодо запального потенціалу та клінічної картини захворювання.

Для встановлення діагнозу ХАА необхідна відповідна клінічна картина захворювання, високий рівень IgG проти борелій комплексу $B$. burgdorferi sensu lato та ricтологічні результати, які підтверджують цю патологію [35].

XАA зазвичай виникає в осіб старше 50 років і лише у виняткових випадках трапляється у дитячому віці. Andres C. et al. [36] описують два клінічні випадки XАA у дітей 8 та 10 років, тому про цей прояв Лайм-бореліозу слід пам'ятати педіатрам і дитячим інфекціоністам.

\section{Діагностика}

Центри з контролю та профрілактики захворювань у США рекомендують 2-ступеневий метод для діагностики хвороби Лайма. Перший крок, як правило, складається з тесту ІФА, за допомогою якого ми можемо виявити титри IgМ та IgG до Borrelia burgdorferi.

Якщо результат ІФА негативний та дослідження проводилося протягом перших 30 діб від початку симптомів
- необхідно повторити ІФА через 4-6 тиж після першого дослідження.

Якщо дослідження проводилося через 30 діб і більше з моменту появи симптомів - подальші обстеження не проводяться, необхідно розглянути інші можливі діагнози.

У випадку позитивних або сумнівних результатів серологічного дослідження, другим кроком є їх підтвердження методом вестерн-блот.

При симптомах хвороби Лайма, які виявляються впродовж 30 діб або менше, проводять визначення IgM та IgG методом вестерн-блот.

Якщо симптоми наявні більш ніж 30 діб, визначають тільки IgG [37].

Вестерн-блот слід проводити лише після нещодавнього позитивного або сумнівного результату ІФА з метою уникнення несправжньо-позитивних або несправжньо-негативних результатів.

За відсутності лікування титри IgМ зазвичай досягають максимуму через 6-8 тиж після зараження і зникають протягом 4-6 міс., хоча нерідко залишаються підвищеними протягом декількох місяців або років.

IgG до B. burgdorferi, як правило, виявляються протягом 6-8 тиж після зараження, досягають піку протягом 4-6 міс. і залишаються підвищеними необмежено довго. На пізніх стадіях захворювання (більше 4-6 тиж після зараження) результати IgG більш корисні для діагностики, ніж результати IgM.

Слід зазначити, що антитіла можуть залишатися позитивними роками після адекватного лікування і не можуть використовуватися для того, щоб відрізнити активну та неактивну фрази захворювання. Наявність позитивних IgM з негативними IgG до B. burgdorferi більше ніж через 6-8 тиж після контакту з кліщем, за відсутності специорічної терапії у пацієнта, означають несправжньо-позитивний результат.

ПЛР може бути використана для виявлення ДНК В. burgdorferi у крові, лікворі, сечі або синовіальній рідині протягом декількох тижнів після зараження. Полімеразна ланцюгова реакція позитивна у третини пацієнтів 3 активною хворобою Лайма.

Хоча більшість результатів ПЛР стають негативними впродовж 2 тиж після антимікробної терапії, частина 3 них залишається позитивною впродовж багатьох років після лікування. Не рекомендовано проводити ПлР ліквору через його низьку чутливість. Водночас ПлР синовіальної рідини є важливим діагностичним критерієм.

У пацієнтів з Лайм-артритом, як правило, спостерігається запальний характер синовіальної рідини: кількість клітин коливається в межах 500-98 000/мкл. У дорослих пацієнтів синовіальну рідину слід також до- 


\section{ОГЛЯДИ ТА ЛЕКЦІї}

сліджувати на наявність кристалів, щоб виключити подагру та псевдоподагру.

У пацієнтів з хворобою Лайма кількість лейкоцитів у крові може бути нормальною або підвищеною, швидкість осідання еритроцитів (ШОЕ) зазвичай підвищена. Значення аспартатамінотрансферази в сироватці крові може перевищувати нормальні показники. При тестуванні комплементу рівні С3 та С4 зазвичай нормальні або дещо перевищують норму. Результати тесту на антинуклеарні антитіла (ANA) та ревматоїдний фрактор негативні [38].

Пост-медикаментозний синдром хвороби Лайма

Пост-медикаментозний синдром хвороби Лайма (ПМСХЛ) - це наявність у пацієнта стійких суб'єктивних симптомів без об'єктивних проявів, які зберігаються щонайменше 6 міс. після завершення лікування.

Антибіотикотерапія більшості клінічних фрорм Лаймбореліозу есрективна впродовж 2-4 тиж. Але у деяких пацієнтів після вчасного і адекватного лікування залишаються такі неспецифічні симптоми, як втома, артралгії, міалгії та когнітивні порушення. У доступній літературі є суперечливі дані стосовно ПМСХЛ: на думку лікарів, що входять до Міжнародної спілки науковців 3 хвороби Лайма та асоційованих хвороб (ILADS), ПМСХЛ $\epsilon$ хронічною хворобою Лайма і вони пов'язують його зі стійкістю інфекції, що вимагає тривалої антибіотикотерапії для інволюції симптомів [39]. Водночас Oliviera C.R. et al. [40] стверджують, що проведення чотирьох плацебо-контрольованих клінічних випробувань 3 метою оцінки користі від використання тривалої антибіотикотерапії для пацієнтів з ПМСХЛ не підтвердило її доцільність. Ці дослідження були повторно проаналізовані та розглянуті Klempner et al. [41] і вчені дійшли згоди, що від тривалого лікування антибіотиками немає суттєвих стійких переваг, лише значні ризики побічних явищ. $Є$ велика кількість доказів того, що лікування тривалими курсами антибіотиків не показано для пацієнтів з постмедикаментозним синдромом хвороби Лайма.

Також слід пам'ятати, що наявність ДНК В. burgdorferi після лікування антибіотиками не свідчить про триваючу інфекцію, а повторні епізоди мігруючої еритеми зумовлені повторним інфікуванням іншим видом борелій, а не рецидивом раніше пролікованої інфекції.

Для встановлення діагнозу ПМСХЛ необхідно досконало зібрати анамнез захворювання, виявити типові клінічні ознаки Лайм-бореліозу, підтвердити наявність інфекції B. burgdorferi, а також виявити стійкі або рецидивні симптоми, що почалися протягом 6 міс. після завершення лікування 3 приводу раннього або пізнього Лайм-бореліозу і які зберігаються 6 міс. або довше. Крім того, інші соматичні, психіатричні або поведінкові причини неспецифічних суб'єктивних симптомів повинні бути виключені [42].

\section{Профрілактика}

Хвороба Лайма має сезонний характер, пік захворюваності припадає на період між квітнем і жовтнем, що пов'язано з підвищеною активністю людей на відкритих територіях порівняно $з$ іншими місяцями року. Але у зв'язку з глобальним потеплінням сезонність починає зміщуватися і все частіше повідомляється про укуси кліщів ранньою весною і, навіть, взимку. На сьогодні збільшується загальна чисельність кліщів і кількість кліщів, інорікованих бореліями, що у свою чергу призводить до зростання кількості інфрікованих дорослих і дітей.

Впродовж багатьох років захворюваність на Лаймбореліоз в ендемічних регіонах України невпинно зростає, сорормовані стійкі ендемічні зони з великою чисельністю переносників хвороби Лайма, які інфріковані бореліями [43].

Саме тому основними заходами для запобігання захворюванню на території області $€$ проведення акарицидної обробки лісопаркових зон і місць масового відпочинку людей, здійснення картування місцевості 3 визначенням осередків концентрації кліщів і відсотка інорікованості кліщів бореліями.

Одним 3 методів профрілактики інфікування B. burgdorferi та іншими патогенними мікроорганізмами, які переносяться кліщами роду Ixodes - це зменшення можливості контакту з ними. Для зниження ризику іноікування рекомендують використовувати відповідний одяг (кепка або панамка, світлий однотонний одяг 3 довгими рукавами, який щільно прилягає до тіла, довгі штани, закрите взуття) на прогулянках у лісових і паркових зонах, засоби від кліщів (репеленти), ретельно оглядати тіло дитини після кожної прогулянки та якомога швидше видаляти кліщів, щоб запобігти передачі збудників іноекції людині.

Диетилтолуамід (ДЕТА) - найесрективніший репелент, та його рідко використовують через значне занепокоєння щодо його потенційної токсичності, але після місцевого застосування абсорбується лише дуже мала його кількість і сполука швидко виводиться з організму. Варто використовувати засоби, які містять 25-35 \% ДЕТА у своєму складі. Ïх ефект триває до 6 год. Дослідження показують, що засоби з вищим відсотком ДЕТА захищають довше. Наприклад, репелент з 10 \% ДЕТА відлякує шкідників протягом 2 год, тоді як засіб з вмістом ДЕТА $24 \%$ забезпечує захист на 5 год. Але дослідження також показують, що продукти з ДЕТА понад 30 \% не забезпечують тривалішого і кращого захисту. Американська академія педіатрії (ААП) рекомендує використовувати для дітей репеленти не більше, ніж з 30 \% ДЕТА. Водночас ААП забороняє використовувати репеленти дітям віком менше 2 міс. Використовувати репеленти дітям 
слід 3 великою обережністю: не можна розпилювати спрей на обличчя, при поверненні з прогулянки репелент треба змити зі шкіри, а одяг випрати, уникати нанесення репеленту на ушкоджену шкіру (рани, запальні елементи, сонячні опіки). Не слід використовувати засоби, що поєднують ДЕТА із сонцезахисним кремом, бо ДЕТА може зменшити фрактор захисту від сонця (SPF) і зробити його менш ефективним. Також такі комбіновані засоби (ДЕТА + SPF) можуть призводити до надмірного контакту дитини з ДЕТА, оскільки сонцезахисний крем потрібно часто наносити повторно.

До складу репелентів, крім ДЕТА, можуть входити речовини, дозволені Агентством з охорони навколишнього середовища США (ЕРА): пікаридин, олія лимонного евкаліпту, перметрин, IR3535 [44]. Американське товариство фахівців 3 інфекційних хвороб США (Infectious Diseases Society of America, IDSA) не рекомендує регулярне використання антимікробної профрілактики для запобігання хвороби Лайма після укусу кліща. Одноразова доза доксицикліну може бути запропонована дорослим пацієнтам (200 мг/доза) та дітям будь-якого віку з масою тіла менше 45 кг в дозі 4,4мг/кг одноразово при умові, що: виявлений кліщ ідентифрікований як доросла особина або німфа I. scapularis; тривалість прикріплення рівна або перевищує 36 год; 3 моменту видалення кліща минуло не більше 72 год; місцевий рівень зараження кліщів B. burgdorferi рівний або перевищує 20 \%; немає протипоказань до застосування доксицикліну.

Хіміопрофрілактика, проведена пізніше ніж 72 год після видалення кліща, не гарантує її ефективності.

На сьогодні невідомо, чи вплине антибіотикопрофрілактика Лайм-бореліозу після укусу кліща на розвиток гранулоцитарного анаплазмозу і бабезіозу.

Згідно 3 настановою «Клінічна оцінка, лікування та профрілактика хвороби Лайма, гранулоцитарного анаплазмозу людини та бабезіозу: рекомендації з клінічної практики Товариства інорекційних хвороб Америки», профрілактика Лайм-бореліозу у вагітних має базуватися на оцінці ризиків розвитку хвороби чи побічних дій антибіотикотерапії. Науковці вважають, що амоксицилін не може замінити доксициклін для людей, яким протипоказана профрілактика доксицикліном, через відсутність даних щодо ефективності короткого курсу амоксициліну для профрілактики Лайм-бореліозу. Також автори настанови наголошують, що не потрібно обстежувати кліщів 3 метою виявлення в них борелій $[45,46]$.

\section{Лікування}

Лікування мігруючої еритеми.

\section{Діти менше 8 років}

Амоксицилін - 50 мг/кг/добу, розділений на 3 дози (не більше 500 мг на дозу) 14-21 день. або

Цефуроксим аксетил - 30 мг/кг/добу, розділені на 2 дози (не більше 500 мг на дозу) 14-21 день.

Діти більше 8 років

Доксициклін 4,4 мг/кг/добу, розділені на 2 дози (не більше 100 мг на дозу) 10-21 день.

Доксициклін - препарат першої лінії для лікування хвороби Лайма, був винайдений після тетрацикліну 3 подібними побічними ефектами, включаючи ризик зміни кольору емалі зубів та гіпоплазію емалі зубів, при застосуванні у дітей до 8 років в період одонтогенезу. Але подальші дослідження вказують, що доксициклін, на відміну від інших тетрациклінів, значно меншою мірою зв'язується 3 кальцієм і, за даними останніх наукових досліджень, не викликає зміну кольору емалі або гіпоплазії емалі зубів у дітей до 8 років. Тому Центри 3 контролю та профрілактики захворювань у США (англ. Centers for Disease Control and Prevention, CDC) рекомендують використовувати доксициклін для лікування гострої та хронічної Ку-гарячки та кліщових рикетсіозів у дітей з масою тіла менше 45 кг [47].

«Червона книга» Американської Асоціації педіатрії (The 2018 AAP "Red Book") стверджує, що «доксициклін можна застосовувати протягом короткого періоду часу (тобто 21 день або менше), не враховуючи вік пацієнта...» [48].

Антибіотики з групи макролідів як препарати першої лінії для лікування ранньої стадії Лайм-бореліозу використовувати не рекомендується. Макроліди є препаратами резерву, до яких слід вдаватися лише у випадках, коли пацієнти не переносять амоксицилін, цесуроксим аксетил або доксициклін.

Рекомендовані дози при застосуванні макролідів як препаратів резерву для лікування Лайм-бореліозу у дітей:

Азитроміцин 10 мг/кг/добу, максимум 500 мг на добу, 7-10 днів.

Кларитроміцин 7,5 мг/кг 2 рази/добу, не більше 500 мг/доза, 14-21 день.

Еритроміцин 12,5 мг/кг 4 рази/добу, не більше 500 мг/доза, 14-21 день.

Цефалоспорини 1-го покоління, такі як цефралексин, не ефективні при Лайм-бореліозі і не використовуються для його лікування.

Цестріаксон рекомендовано для лікування пацієнтів з Лайм-бореліозом із залученням в процес нервової системи або при розвитку атріовентрикулярної блокади 3-го ступеня. Хоча він ефективний для лікування ранніх стадій хвороби Лайма, його дія має побічні наслідки і не переважає над рекомендованими пероральними антимікробними засобами. 


\section{Лікування нейробореліозу}

Лікування паралічу лицевого нерва (ізольованої форми) проводиться згідно зі схемами лікування МЕ.

Лікування Лайм-менінгіту або радикулоневриту

Дітям менше 8 років призначають цефтріаксон 100 мг/кг/добу, розділені на 2 введення (не більше 2 г/добу) 14-21 день.

Ураження черепно-мозкових нервів у пацієнтів 3 хворобою Лайма часто поєднується зі симптомами менінгіту і лімфоцитарним плеоцитозом у лікворі. Спинномозкова пункція показана при клінічних підозрах на ураження ЦНС (інтенсивний та тривалий біль голови).

Лікування Лайм-кардиту при помірних його проявах (AB-блокада 1-го ступеня з PR інтервалом менше 300 мс) проводиться згідно зі схемою лікування ME.

Тяжкий ступінь Лайм-кардиту (АВ-блокада 1-го ступеня з PR інтервалом більше 300 мс, АВ-блокада 2-го, 3-го ступенів):

*Цефтріаксон 50-75 мг/кг/д в/в у 2 введення (не більше 2 г/добу) 14-21 день.

*Після усунення симптомів і повної АВ-блокади можна розглянути можливість переходу на пероральні антибіотики для завершення курсу лікування.

Лікування Лайм-артриту проводиться згідно зі схемою терапії ME, але із збільшенням тривалості курсу до 28 днів.

Рекомендована також парентеральна антибіотикотерапія (курс 14-28 днів)

Цефртріаксон 50-75 мг/кг/д в/в 1 раз/добу (не більше 2 г/добу).

Цефотаксим 150-200 мг/кг/д, розділені на 3-4 дози (максимум 6 г/добу).
Пеніцилін G 200 000-400 000 ОД/кг/д, розділені на 6 доз, через кожні 4 год (18-24 млн ОД/добу максимум).

Пацієнтам, в яких спостерігаються постійні або періодичні набряки суглобів після рекомендованого курсу пероральної антибіотикотерапії, рекомендоване повторне лікування іншим 4-тижневим курсом пероральних антибіотиків або 2-4-тижневим курсом цефтріаксону довенно.

Наступний 4-тижневий курс пероральної антибіотикотерапії варто призначати пацієнтам, стан суглобів яких покращився після першого курсу антибіотика, але симптоми артриту ще не зникли повністю. Пацієнтам, в яких не відбулось покращення, або спостерігається погіршення стану суглобів після першого курсу, рекомендовано повторний 4-тижневий курс. Якщо немає позитивної динаміки лікування артриту, незважаючи на повторні курси антибіотикотерапії, але ПлР на визначення ДНК борелій в синовіальній рідині негативна (та при можливості синовіальної тканини), рекомендовано симптоматичне лікування.

Симптоматична терапія може складатися з НПЗП або протиревматичних препаратів, таких як гідроксихлорохін, метотрексат. Якщо симптоми синовіїту стійкі і поєднуються зі значним болем та обмеженням функцій суглоба, можна розглянути проведення артроскопічної синовектомії [45].

Захворюваність на Лайм-бореліоз продовжує невпинно зростати у європейському регіоні та в Україні зокрема. Саме тому необхідно підвищувати інформованість лікарів різних спеціальностей про особливості перебігу, методи діагностики, особливості профрілактики та лікування хвороби Лайма в педіатричній практиці.

\section{Література}

1. Попович О.О. Лайм-бореліоз : сучасна проблема інсректології (клінічна лекція) / О.О. Попович // Актуальна інфектологія. - 2016. - № 3. - C. 114-122. DOI: 10.22141/2312-413x.3.12.2016.81725.

2. Куляс С.М. Сучасний погляд на особливості специсічної діагностики, лікування та профілактики Лайм-бореліозу / С.М. Куляс // Biomedical and biosocial anthropology. - 2013. - № 20. C. $245-250$.

3. Updates on Borrelia burgdorferi sensu lato complex with respect to public health / Nataliia Rudenko, Maryna Golovchenko, Libor Grubhoffer [et al.] // Tick-borne Diseases. - 2011. - Vol. 2, N 3. - P. 123-128. DOI: 10.1016/j.ttbdis.2011.04.002.

4. Козловська А. Лайм-бореліоз: сучасний алгоритм діагностики, лікування та профрілактики / А. Козловська // Український медичний часопис. - 2020. 6 квітня : [електронний ресурс]. Режим доступу: https://www.umj.com.ua/article/174194/lajm-borelioz-suchasnijalgoritm-diagnostiki-likuvannya-ta-profilaktiki.

5. Лайм-бореліоз: питання діагностики і терапії / Л.Р. Шостакович-Корецька, І.В. Будаева, А.В. Чергінець [та ін.] // Актуальна інфректологія. - 2014. - № 2 (3). - С. 27-31.

6. Lyme disease [internet]. Access mode : https://emedicine.medscape.com/article/330178-overview. Updated 01.08.2019.

7. Сорокман Т.В. Хвороба Лайма у дитячому віці: погляд на проблему та клінічний випадок / Т.В. Сорокман, П.М. Молдован // Актуальна інфектологія. - 2018. - Т. 6, № 1. - С. 1-6. DOI: 10.22141/2312-413x.6.1.2018.125628.

8. Borrelia burgdorferi infection and Lyme disease in children / Susanna Esposito, Samantha Bosis, Caterina Sabatini [et al.] // 
International Journal of Infectious Diseases. - 2013. - Vol. 17, N 3. P. e153-158. DOI: 10.1016/j.ijid.2012.09.014.

9. Пуренко О.О. Особливості перебігу хвороби Лайма (бореліозу) у дитячому віці / О.О. Пуренко, О.А. Прокопович // Медсестринство. - 2018. - № 4. - С. 50-52.

10. Feder H. M. Jr. Lyme disease in children / H. M. Feder Jr. // Infectious Disease Clinics of North America. - 2008. - Vol. 22, N 2. P. 315-326. DOI: 10.1016/j.idc.2007.12.007.

11. Волоха А.П. Хвороба Лайма (кліщовий бореліоз) у дітей / А.П. Волоха // Інфекційні хвороби. - 2014. - № 1. - С. 80-87.

12. Зінчук О.М. Безеритемні форми лайм-бореліозу: важливість своєчасної діагностики / О.М. Зінчук // Науковий вісник Ужгородського університету. Сер.: Медицина. - Ужгород, 2008. Вип. 34. - С. 60-62.

13. Lyme borreliosis: clinical case definitions for diagnosis and management in Europe / G. Stanek, V. Fingerle, K. P. Hunfeld [et al.] // Clinical Microbiology and Infection. - 2011. - Vol. 17, N 1. - P. 69-79. DOI: 10.1111/j.1469-0691.2010.03175.x.

14. Pearson S. Recognising and understanding Lyme disease / S. Pearson // Nursing Standard. - 2014. - Vol. 29, N 1. - P. 37-43. DOI: 10.7748/ns.29.1.37.e9073.

15. D'Alessandro M. Management of Lyme disease in European children: a review for practical purpose / M. D'Alessandro, A. Loy, E. Castagnola // Current Infectious Disease Reports. - 2017. - Vol. 19, N 8. - P. 27. DOI: 10.1007/s11908-017-0582-9.

16. Lyme disease: a rigorous review of diagnostic criteria and treatment / Andrea T. Borchers, Carl L. Keen, Arthur C. Huntley [et al.] // Journal of Autoimmunity. - 2015. - Vol. 57. - P. 82-115. DOI: 10.1016/j. jaut.2014.09.004.

17. CDC-Neurologic Lyme disease [internet]. - Access mode : https://www.cdc.gov/lyme/treatment/NeurologicLyme.html. Updated - October 23, 2020.

18. Lyme neuroborreliosis in children: Report of nine cases and a review of the literature / $\mathrm{H}$. Guet-Revillet, C. Levy, C. Vallet [et al.] // Archives de Pédiatrie. - 2019. - Vol. 26, N 3. - P. 133-137. DOI: 10.1016/j.arcped.2019.02.010.

19. Validation of a clinical prediction rule to distinguish Lyme meningitis from aseptic meningitis / Keri A. Cohn, Amy D. Thompson, Samir S. Shah [et al.] // Pediatrics. - 2012. - Vol. 129, N 1. - P. e4653. DOI: 10.1542/peds.2011-1215.

20. Allen N. M. Lyme neuroborreliosis: A potentially preventablecause of stroke / Nicholas M. Allen, Heinz Jungbluth // The Journal of Pediatrics. - 2016. - Vol. 170. - P. 334-e1. DOI: 10.1016/j. jpeds.2015.11.077.

21. Lyme disease: What the neuroradiologist needs to know / H. A. Valand, A. Goyal, D. A. Melendez [et al.] // American Journal of Neuroradiology. - 2019. - Vol. 40, N 12. - P. 1998-2000. DOI: 10.3174/ajnr.A6301.

22. Lyme carditis: cardiac abnormalities of Lyme disease / A. C. Steere, W. P. Batsford, M. Weinberg [et al.] // Annals of Internal Medicine. - 1980. - Vol. 93, N 1. - P. 8-16. DOI: 10.7326/0003-481993-1-8.

23. Lyme carditis / Matthew L. Robinson, Takaaki Kobayashi, Yvonne Higgins [et al.] // Infectious Disease Clinics of North America. - 2015. - Vol. 29, N 2. - P. 255-268. DOI: 10.1016/j.idc.2015.02.003.

24. Manifestations of Lyme carditis / Tomislav Kostić, Stefan Momčilović, Zoran D. Perišić [et al.] // International Journal of Cardiology. - 2017. - Vol. 232. - P. 24-32. DOI: 10.1016/j.ijcard.2016.12.169.

25. Yeung C. Diagnosis and treatment of Lyme carditis: JACC review topic of the week / Cynthia Yeung, Adrian Baranchuk // Journal of the American College of Cardiology. - 2019. - Vol. 73, N 6. - P. 717726. DOI: 10.1016/j.jacc.2018.11.035.
26. Mitral valve endocarditis: A rare manifestation of Lyme disease I Osama Haddad, Marc Gillinov, Thomas Fraser [et al.] // The Annals of Thoracic Surgery. - 2019. - Vol. 108, N 2. - P. e85-e86. DOI: 10.1016/j. athoracsur.2018.12.046.

27. Fishe J. N. Lyme myocarditis presenting as chest pain in an adolescent girl / Jennifer N. Fishe, Ronald F. Marchese, James M. Callahan // Pediatric Emergency Care. - 2016. - Vol. 32, N 7. - P. 459461. DOI: 10.1097/PEC.0000000000000654.

28. Chest palpitations in a teenager as an unusual presentation of Lyme disease: case report / Faith Myers, Pooja E. Mishra, Daniel Cortez [et al.] // BMC Infectious Diseases. - 2020. - Vol. 20, N 1. P. 730. DOI: 10.1186/s12879-020-05438-0.

29. Зінчук О.М. Актуальні питання клініки, діагностики та лікування нейробореліозу / О.М. Зінчук // Інфекційні хвороби. 2004. - № 1. - C. 59-64.

30. Summer G. Neurologic manifestations of Lyme borreliosis / G. Summer, T. A. Rupprecht // Revue Neurologique. - 2019. - Vol. 175, N 7-8. - P. 417-419. DOI: 10.1016/j.neurol.2019.07.012.

31. A critical appraisal of the mild axonal peripheral neuropathy of late neurologic Lyme disease / Gary P. Wormser, Franc Strle, Eugene D. Shapiro [et al.] // Diagnostic Microbiology and Infectious Disease. - 2017. - Vol. 87, N 2. - P. 163-167. DOI: 10.1016/j.diagmicrobio.2016.11.003.

32. Steere A. C. Treatment of Lyme arthritis / Allen C. Steere // The Journal of Rheumatology. - 2019. - Vol. 46, N 8. - P. 871-873. DOI: 10.3899/jrheum.190320.

33. Long K. C. Lyme arthritis: An update for clinical practice / Katharine Christina Long, Keri Anne Cohn // Pediatric Emergency Care. - 2018. - Vol. 34, N 8. - P. 588-591. DOI: 10.1097/ PEC. 0000000000001576 .

34. Differences in genotype, clinical features, and inflammatory potential of Borrelia burgdorferi sensu stricto strains from Europe and the United States / Tjaša Cerar, Franc Strle, Daša Stupica [et al.] // Emerging Infectious Diseases. - 2016. - Vol. 22, N 5. P. 818-827. DOI: 10.3201/eid2205.151806.

35. Acrodermatitis chronica atrophicans in children: Report on two cases and review of the literature / V. Maraspin, T. Mrvič, E. RužićSabljić [et al.] // Ticks and Tick-borne Diseases. - 2019. - Vol. 10, N 1. - P. 180-185. DOI: 10.1016/j.ttbdis.2018.10.009.

36. Acrodermatitis chronica atrophicans in two children / Christian Andres, Mahzad Ziai, Harald Bruckbauer [et al.] // International Journal of Dermatology. - 2010. - Vol. 49, N 2. - P. 180-183. DOI: 10.1111/j.1365-4632.2009.04194.x.

37. Lipsett S. C. Diagnosis of Lyme disease in the pediatric acute care setting / Susan C. Lipsett, Lise E. Nigrovic // Current Opinion in Pediatrics. - 2016. - Vol. 28, N 3. - P. 287-293. DOI: 10.1097/ MOP.0000000000000339.

38. Lyme disease workup [internet]. - Access mode : https:// emedicine.medscape.com/article/330178-workup. Updated Aug 01, 2019.

39. Lyme Disease Treatment \& Management. - Access mode : https://emedicine.medscape.com/article/330178-treatment. Updated Aug 01, 2019.

40. Oliveira C. R. Update on persistent symptoms associated with Lyme disease / Carlos R. Oliveira, Eugene D. Shapiro // Current Opinion in Pediatrics. - 2015. - Vol. 27, N 1. - P. 100-104. DOI: 10.1097I MOP.0000000000000167.

41. Treatment trials for post-Lyme disease symptoms revisited / Mark S. Klempner, Phillip J. Baker, Eugene D. Shapiro [et al.] // The American Journal of Medicine. - 2013. - Vol. 126, N 8. - P. 665-669. DOI: 10.1016/j.amjmed.2013.02.014. 


\section{ОГЛЯДИ ТА ЛЕКЦІї}

42. Update of the Swiss guidelines on post-treatment Lyme disease syndrome / Johannes Nemeth, Enos Bernasconi, Ulrich Heininger [et al.] // Swiss Medical Weekly. - 2016. - Vol. 146. - P. w 14353. DOI: 10.4414/smw.2016.14353.

43. Зінчук О.М. До питання екстреної профрілактики Лаймбореліозу / О.М. Зінчук // Acta medica Leopoliensia. - 2016. - T. 22, № 2. - C. 39-43.

44. Sood S. K. Lyme disease in children / Sunil K. Sood // Infectious disease clinics of North America. - 2015. - Vol. 29, N 2. - P. 281-294. DOI: 10.1016/j.idc.2015.02.011.

45. The clinical assessment, treatment, and prevention of Lyme disease, human granulocytic anaplasmosis, and babesiosis: clinical practice guidelines by the Infectious Diseases Society of America /
Gary P. Wormser, Raymond J. Dattwyler, Eugene D. Shapiro [et al.] // Clinical Infectious Diseases. - 2006. - Vol. 43, N 9. - P. 1089-1134. DOI: $10.1086 / 508667$

46. Tick Bite Prophylaxis [internet]. - Access mode : https://www. cdc.gov/ticks/tickbornediseases/tick-bite-prophylaxis.html.

47. The end of a dogma: the safety of doxycycline use in young children for malaria treatment / Tiphaine Gaillard, Sébastien Briolant, Marylin Madamet [et al.] // Malaria Journal. - 2017. - Vol. 16, N 1. P. 148. DOI: 10.1186/s12936-017-1797-9.

48. AAP News. When can doxycycline be used in young children? by H. Cody Meissner M.D., FAAP February 27, 2020 [internet] - Access mode : https://www.aappublications.org/news/aapnewsmag/2020/02/27/idsnapshot022720.full.pdf.

\section{References}

1. Popovych, O.O. (2016). Lyme borreliosis: a modern problem of infectology (clinical lecture). Aktualna infektolohima - Topical Wnfectology, 3, 114-122. DOI: 10.22141/2312-413x.3.12.2016.817 25[in Ukrainian]

2. Kulias, S.M. (2013). Modern view on the features of specific diagnosis, treatment and prevention of Lyme borreliosis. Biomedical and Biosocial Anthropology, 20, 245-250 [in Ukrainian].

3. Rudenko, N., Golovchenko, M., Grubhoffer, L., \& Oliver, J.H.Jr. (2011). Updates on Borrelia burgdorferi sensu lato complex with respect to public health. Tick-borne Diseases, 2 (3), 123-128. DOI: 10.1016/j. ttbdis.2011.04.002.

4. Kozlovska, A. (2020). Lyme borreliosis: a modern algorithm for diagnosis, treatment and prevention. Ukrainsky medychny chasopys - Ukrainian Medical Journal, 6 April [E-resourse]. https://www.umj. com.ua/article/174194/lajm-borelioz-suchasnij-algoritm-diagnostikilikuvannya-ta-profilaktiki [in Ukrainian].

5. Shostakovych-Koretska, L.R., Budaeva, I.V., Cherhinets, A.V., Mavrutenkov, V.V., \& Marchenko, N.E. (2014). Lyme borreliosis: issues of diagnosis and therapy. Aktualna infektolohiia - Topical Infectology, 2 (3), 27-31 [in Ukrainian].

6. Lyme disease. Retrieved from: https://emedicine.medscape. com/article/330178-overview. Updated 01.08.2019.

7. Sorokman, T.V., \& Moldovan, P.M. (2018). Lyme disease in childhood: a look at the problem and a clinical case. Aktualna infektolohiia - Topical Infectology, 6 (1), 1-6. DOI: 10.22141/2312413x.6.1.2018.125628 [in Ukrainian].

8. Esposito, S., Bosis, S., Sabatini, C., Tagliaferri, L., \& Principi, N. (2013). Borrelia burgdorferi infection and Lyme disease in children. International Journal of Infectious Diseases, 17 (3), e153-158. DOI: 10.1016/j.ijid.2012.09.014.

9. Purenko, O.O., \& Prokopovych, O.A (2018). Features of Lyme disease (borreliosis) in childhood. Medsestrynstvo - Nursing, 4, 50-52 [in Ukrainian].

10. Feder, H.M.Jr. (2008). Lyme disease in children. Infectious Disease Clinics of North America, 22, 2, 315-326. DOI: 10.1016/j. idc.2007.12.007.

11. Volokha, A.P. (2014). Lyme disease (tick-borne borreliosis) in children. Infektsiini khvoroby - Infectious Diseases, 1, 80-87 [in Ukrainian].
12. Zinchuk, O.M. (2008). Grade-free forms of Lyme disease: the importance of timely diagnosis. Naukovyi visnyk Uzhhorodskoho universytetu - Scientific Bulletin of Uzhhorod University. Ser.: Medytsyna. Uzhhorod, (34), 60-62 [in Ukrainian].

13. Stanek, G., Fingerle, V., Hunfeld, K. P., Jaulhac, B., Kaiser, R., Krause, A., ... \& Gray, J. (2011). Lyme borreliosis: clinical case definitions for diagnosis and management in Europe. Clinical Microbiology and Infection, 17 (1), 69-79. DOI: 10.1111/j.14690691.2010.03175.x.

14. Pearson, S. (2014). Recognising and understanding Lyme disease. Nursing Standard, 29 (1), 37-43. DOI: 10.7748/ns.29.1.37.e9073.

15. D'Alessandro, M., Loy, A., \& Castagnola, E. (2017). Management of Lyme disease in European children: a review for practical purpose. Current Infectious Disease Reports, 19 (8), 27. DOI: $10.1007 /$ s11908-017-0582-9.

16. Borchers, A., Keen, C.L., Huntley, A.C., \& Gershwin, M.E. (2015). Lyme disease: a rigorous review of diagnostic criteria and treatment. Journal of Autoimmunity, 57, 82-115. DOI: 10.1016/j. jaut.2014.09.004.

17. CDC-Neurologic Lyme disease. Retrieved from: https://www. cdc.gov/lyme/treatment/NeurologicLyme.html. Updated - October 23, 2020

18. Guet-Revillet, H., Levy, C., Vallet, C., Maghraoui-Slim, V., Dommergues, M.A., Hentgen, V., ... \& Ferroni, A. (2019). Lyme neuroborreliosis in children: Report of nine cases and a review of the literature. Archives de Pédiatrie, 26 (3), 133-137. DOI: 10.1016/j. arcped.2019.02.010.

19. Cohn, K.A., Thompson, A.D., Shah, S.S., Hines, E.M., Lyons, T.W., Welsh, E.J., \& Nigrovic, L.E. (2012). Validation of a clinical prediction rule to distinguish Lyme meningitis from aseptic meningitis. Pediatrics, 129 (1), e46-e53. DOI: 10.1542/peds.2011-1215.

20. Allen, N.M., \& Jungbluth, H. (2016). Lyme neuroborreliosis: A potentially preventable cause of stroke. The Journal of Pediatrics, 170 334-e1. DOI: 10.1016/j.jpeds.2015.11.077.

21. Valand, H.A., Goyal, A., Melendez, D.A., Matharu, S.S., Mangat, H.S., \& Tu, R.K. (2019). Lyme disease: What the neuroradiologist needs to know. American Journal of Neuroradiology, 40 (12), 19982000. DOI: 10.3174/ajnr.A6301. 
22. Steere, A.C., Batsford, W.P., Weinberg, M., Alexander, J., Berger, H.J., Wolfson, S., \& Malawista, S.E. (1980). Lyme carditis: cardiac abnormalities of Lyme disease. Annals of Internal Medicine, 93 (1), 8-16. DOI: 10.7326/0003-4819-93-1-8.

23. Robinson, M.L., Kobayashi, T., Higgins, Y., Calkins, H., \& Melia, M.T. (2015). Lyme carditis. Infectious Disease Clinics of North America, 29 (2), 255-268. DOI: 10.1016/j.idc.2015.02.003.

24. Kostić, T., Momčilović, S., Perišić, Z.D., Apostolović, S.R., Cvetković, J., Jovanović, A. et al. (2017). Manifestations of Lyme carditis. International Journal of Cardiology, 232, 24-32. DOI: 10.1016/j. ijcard.2016.12.169.

25. Yeung, C., \& Baranchuk, A. (2019). Diagnosis and treatment of Lyme carditis: JACC review topic of the week. Journal of the American College of Cardiology, 73 (6), 717-726. DOI: 10.1016/j. jacc.2018.11.035.

26. Haddad, O., Gillinov, M., Fraser, Th., Shrestha, N., \& Pettersson, G.B. (2019). Mitral Valve Endocarditis: A Rare Manifestation of Lyme disease. The Annals of Thoracic Surgery, 108 (2), e85-e86. DOI: 10.1016/j.athoracsur.2018.12.046.

27. Fishe, J.N., Marchese, R.F., \& Callahan, J.M. (2016). Lyme myocarditis presenting as chest pain in an adolescent girl. Pediatric Emergency Care, 32 (7), 459-461. DOI: 10.1097/PEC.0000000000000654.

28. Myers, F., Mishra, P. E., Cortez, D., \& Schleiss, M. R. (2020). Chest palpitations in a teenager as an unusual presentation of Lyme disease: case report. BMC Infectious Diseases, 20 (1), 730. DOI: 10.1186/s12879-020-05438-0.

29. Zinchuk, O.M. (2004). Topical issues of clinic, diagnosis and treatment of neuroborreliosis. Infektsiyni khvoroby - Infectious Diseases, 1, 59-64 [in Ukrainian].

30. Summer, G., \& Rupprecht, T.A. (2019). Neurologic manifestations of Lyme Borreliosis. Revue Neurologique, 175 (7-8), 417-419. DOI: 10.1016/j.neurol.2019.07.012.

31. Wormser, G.P., Strle, F., Shapiro, E.D., Dattwyler, R.J., Auwaerter, P.G. (2017). A critical appraisal of the mild axonal peripheral neuropathy of late neurologic Lyme disease. Diagnostic Microbiology and Infectious Disease, 87 (2), 163-167. DOI: 10.1016/j.diagmicrobio.2016.11.003.

32. Steere, A.C. (2019). Treatment of Lyme arthritis. The Journal of Rheumatology, 46 (8), 871-873. DOI: 10.3899/jrheum.190320.

33. Long, K.C., \& Cohn, K.A. (2018). Lyme arthritis: An update for clinical practice. Pediatric Emergency Care, 34 (8), 588-591. DOI: 10.1097/PEC.0000000000001576.

34. Cerar, T., Strle, F., Stupica, D., Ruzic-Sabljic, E., McHugh, G., Steere, A.C., Strle, K. (2016). Differences in genotype, clinical features, and inflammatory potential of Borrelia burgdorferi sensu stricto strains from Europe and the United States. Emerging Infectious Diseases, 22 (5), 818-827. DOI: 10.3201/eid2205.151806.

35. Maraspin, V., Mrvič, T., Ružić-Sabljić, E., Jurčić, V., \& Strle, F.
(2019). Acrodermatitis chronica atrophicans in children: Report on two cases and review of the literature. Ticks and Tick-borne Diseases, 10 (1), 180-185. DOI: 10.1016/j.ttbdis.2018.10.009.

36. Andres, Ch., Ziai, M., Bruckbauer, H., Ring, J., \& Heidelore, H. (2010). Acrodermatitis chronica atrophicans in two children. International Journal of Dermatology, 49 (2), 180-183. DOI: 10.1111/j.13654632.2009.04194.x.

37. Lipsett, S C., \& Nigrovic, L.E. (2016). Diagnosis of Lyme disease in the pediatric acute care setting. Current Opinion in Pediatrics, 28 (3), 287-293. DOI: 10.1097/MOP.0000000000000339.

38. Lyme disease workup. Retrieved from: https://emedicine.medscape.com/article/330178-workup. Updated Aug 01, 2019.

39. Lyme disease treatment \& management. Retrieved from: https://emedicine.medscape.com/article/330178-treatment. Updated Aug 01, 2019.

40. Oliveira, C.R., \& Shapiro, E.D. (2015). Update on persistent symptoms associated with Lyme disease. Current Opinion in Pediatrics, 27 (1), 100-104. DOI: 10.1097/MOP.0000000000000167.

41. Klempner, M.S., Baker, Ph.J., Shapiro, E.D., Marques, A., Dattwyler, R.J., Halperin, J.J., \& Wormser, G.P. (2013). Treatment trials for post-Lyme disease symptoms revisited. The American Journal of Medicine, 126 (8), 665-669. DOI: 10.1016/j.amjmed.2013.02.014.

42. Nemetha, J., Bernasconib, E., Heiningerc, U., Abbasd, M., Nadale, D., \& Strahmf, C. (2016). Update of the Swiss guidelines on post-treatment Lyme disease syndrome. Swiss Medical Weekly, 146, w 14353. DOI: 10.4414/smw.2016.14353.

43. Zinchuk, O.M. (2016). On the issue of emergency prevention of Lyme borreliosis. Acta medica Leopoliensia, 22 (2), 39-43 [in Ukrainian].

44. Sood, S.K. (2015). Lyme disease in children. Infectious Disease Clinics of North America, 29 (2), 281-294. DOI: 10.1016/j. idc.2015.02.011.

45. Wormser, G.P., Dattwyler, R.J., Shapiro, E.D., Halperin, J.J., Steere, A.C., Klempner, M.S. et al. (2006). The clinical assessment, treatment, and prevention of lyme disease, human granulocytic anaplasmosis, and babesiosis: clinical practice guidelines by the Infectious Diseases Society of America. Clinical Infectious Diseases, 43 (9), 1089-1134. DOI: 10.1086/508667.

46. Tick bite prophylaxis. Retrieved from: https://www.cdc.gov/ ticks/tickbornediseases/tick-bite-prophylaxis.html.

47. Gaillard, T., Briolant, S., Madamet, M., \& Pradines, B. (2017). The end of a dogma: the safety of doxycycline use in young children for malaria treatment. Malaria Journal, 16 (1), 148. DOI: 10.1186/ s12936-017-1797-9.

48. AAP News. When can doxycycline be used in young children? by H. Cody Meissner M.D., FAAP- February 27, 2020. https://www.aappublications.org/news/aapnewsmag/2020/02/27/idsnapshot022720. full.pdf. 


\section{ОГЛЯДИ ТА ЛЕКЦІї}

\section{LYME DISEASE IN CHILDREN NOWADAYS}

H.O. Lytvyn, N.R. Basa

Danylo Halytsky Lviv National Medical University

SUMMARY. Based on a review of the literature, the latest data on Lyme disease in children are presented. Information on the etiology, epidemiology, characteristic clinical symptoms and the course of Lyme borreliosis (LB) in pediatric practice is summarized. We describe current data on the methods of Lyme disease diagnosis and treatment, doses and medicines depending on the stage and form of the disease, which are approved by the US Centers for Disease Control and Prevention (CDC) and the American Society of Infectious Diseases (IDSA) for the treatment of $L D$ in pediatrics.

Recommendations for the prevention of Lyme disease are given.

Epidemiological data from many countries in Europe and the United States indicate a significant increase in diagnosed cases of Lyme disease due to the use in medical practice highly informative diagnostic methods such as enzyme-linked immunosorbent assay (ELISA) and immunoblot. Today there is a lot of information and researches on Lyme borreliosis in adults as opposed to children.

That is why our literature review is dedicated to Lyme disease in pediatric practice.

Key words: Lyme disease; ixodes ticks; immunoblot; Lyme arthritis; Lyme carditis; children.

\section{Відомості про авторів:}

Литвин Галина Орестівна - к. мед. н., доцентка, завідувачка кафредри Дитячих інсрекційних хвороб Львівського національного медичного університету імені Данила Галицького; e-mail: golytvyn2012@gmail.com

ORCID: https://orcid.org/0000-0002-6902-1024

Баса Нателла Романівна - аспірантка кафедри дитячих інфекційних хвороб Львівського національного медичного університету ім. Данила Галицького; e-mail: natella.apfel@ gmail.com

ORCID: https://orcid.org/0000-0002-2117-0151

\section{Information about the authors:}

Lytvyn H.O. - PhD, Associate Professor, Head of the Department of Pediatric Infectious Diseases, Danylo Halytsky Lviv National Medical University; e-mail: golytvyn2012@gmail. com

ORCID: https://orcid.org/0000-0002-6902-1024

Basa N.R. - PhD student at the Department of Pediatric Infectious Diseases, Danylo Halytsky Lviv National Medical University; e-mail: natella.apfel@gmail.com

ORCID: https://orcid.org/0000-0002-2117-0151

Конфрлікту інтересів немає.

Authors have no conflict of interest to declare.

Отримано 11.04.2021 p. 